\title{
EXTREMELY LOCALLY ADVANCED OVARIAN MALIGNANT MIXED MULLERIAN TUMOR IN 37-YEARS-OLD FEMALE
}

\author{
Gjorgji Jota ${ }^{1}$, Radomir Gelevski ${ }^{2}$, Zoran Karadzov ${ }^{1}$, Redzep Selmani ${ }^{1}$, Magdalena Genadieva-Dimitrova ${ }^{3}$, \\ Margarita Peneva ${ }^{4}$, Vesna Jovanovska-Manevska² \\ ${ }^{1}$ University Clinic for Digestive Surgery, Skopje \\ ${ }^{2}$ General Hospital Kumanovo, Kumanovo \\ ${ }^{3}$ University Clinic for Gastroenterohepatology, Skopje \\ ${ }^{4}$ University Clinic for Plastic and Reconstructive Surgery, Skopje
}

Corresponding author: Gjorgji Jota, University Clinic for Digestive Surgery, Skopje, email: jotamak@hotmail.com

\begin{abstract}
Ovarian carcinosarcomas, rare variant of ovarian carcinoma, composed of both carcinomatous and mesenchymal components, solid and/or cystic, fleshy and hemorrhagic, frequently spreading beyond the ovary, are treated with surgery and adjuvant chemotherapy according to the treatment principles of ovarian carcinomas due to the small number of reported cases and lack of randomized studies. We report a case of a 37-year-old woman with clinical signs of extremely locally advanced tumor of ovarian origin, infiltrating the lower left quadrant of the abdominal wall with necrosis of the covering skin. Prior biopsy of the left ovary and omentum confirmed poorly differentiated serous adenocarcinoma. Bulky tumor the size of a child's head, originating from the left ovary and infiltrating into the lower left quadrant abdominal wall was debulked with wide excision of the abdominal wall and creation of wide defect of the lower left part of abdominal wall covered with Dexon mesh. After the recovery, the medial part of the defect with exposed mesh was closed with pedicled tensor fasciae latae fasciomyocutaneous flap, while the lateral part of the defect was covered with split thickness skin graft. Optimal surgical cytoreduction and adjuvant chemotherapy in case of extremely locally advanced ovarian malignant Müllerian tumor provide satisfactory recurrence-free survival period.
\end{abstract}

Keywords: locally advanced ovarian mixed tumor, carcinosarcoma, surgical debulking, adjuvant chemotherapy

\section{BACKGROUND}

Ovarian carcinosarcomas, also called malignant mixed Mülleriantumours (MMMT) are rare variant of ovarian cancer, accounting for less than $1 \%$ of all ovarian tumors, with fewer than 400 cases reported in the literature $[1,2,3]$. Carcinosarcomas pathologically consist of mixture of two malignant components, epithelial and mesenchymal, occurring throughout the female genital tract, most commonly in the uterus. Ovarian carcinosarcomas are three times less prevalent than those of the uterus [4]. According to the WHO, carcinosarcomas are regarded as metaplastic carcinomas and are supposed to be of epithelial monoclonal origin [5].
Histologically, carcinosarcomas are composed of both carcinomatous and mesenchymal components, which may be either homologous (originating from tissue normally present in the ovary) or heterologous (containing osteoid, chondroid or rhabdomyoid cells). Macroscopically the tumors are solid and/or cystic, fleshy and hemorrhagic and frequently spread beyond the ovary and over the peritoneal surfaces.

The stage classification used for carcinosarcoma of the ovary is the same FIGO system that is applied to the other ovarian adenocarcinomas.

The treatment principles of ovarian carcinosarcomas are the same as those for epithelial ovarian cancer, but the evidence for doing so is lacking due 
to the small number of cases and lack of randomized studies. This is also valid as far as adjuvant chemotherapy is concerned.

Ovarian carcinosarcoma carry a particularly unfavorable prognosis. No effective chemotherapeutic regimen and radiotherapy exists. Optimal cytoreductive surgical debulking is crucial and the FIGO stage is considered as the only prognostic factor [3].

\section{CASE REPORT}

37-year-old woman was admitted at the Clinic for Digestive Surgery in Skopje with clinical signs of extremely locally advanced tumor, of ovarian origin, infiltrating the lower left quadrant of the abdominal wall. Upon clinical examination, large tumor the size of a child's head, with signs of necrosis and hemorrhage, completely infiltrating the full thickness of the lower abdominal wall and necrosis of the covering skin was established. Laboratory examination upon admission revealed $\mathrm{RBC} 2.58 \times 10^{12} / \mathrm{L}$, hemoglobin $67 \mathrm{~g} / \mathrm{L}$, hematocrit $0.220 \mathrm{~L} / \mathrm{L}$, platelets $506 \times 10^{9} / \mathrm{L}$, albumin level $25 \mathrm{~g} / \mathrm{L}$, total protein level $50 \mathrm{~g} / \mathrm{L}$ and CRP $48.9 \mathrm{mg} / \mathrm{L}$.

13 months prior to the admission, the patient underwent surgery because of tumor of the right ovary. During the surgery, the right ovary was removed and biopsy of the left ovary and large omentum was performed. The pathohistological analysis confirmed presence of poorly differentiated serous adenocarcinoma of the right ovary and tube, with tumor implants onto the left ovary and malignant cells in the ascites. The pathological stage was IIC (pTNM=pT2c G3 pNx C4 G3 LV1).

The patient was advised for reoperation and chemotherapy, which were declined by the patient.

7 months prior to the admission, CT of the abdomen and pelvis was performed, verifying large tumorous mass in the lower left quadrant of the abdomen with wide interface with the lower left part of the anterolateral abdominal wall. One month later, second CT of the abdomen and pelvis was performed, verifying several tumorous masses of different sizes, the largest being $9 \mathrm{~cm}$ in diameter; compression of the anterior abdominal wall; enlarged pelvic lymph nodes, secondary deposit with diameter of $35 \mathrm{~mm}$ in the VIII segment of the liver and medium quantity of ascites.

Indication for elective operation was established and median laparotomy was performed. Intra-operative finding was bulky tumor with size of a child's head, originating from the left ovary and infiltrating into the lower left quadrant of the anterolateral abdominal wall (Figure 1).

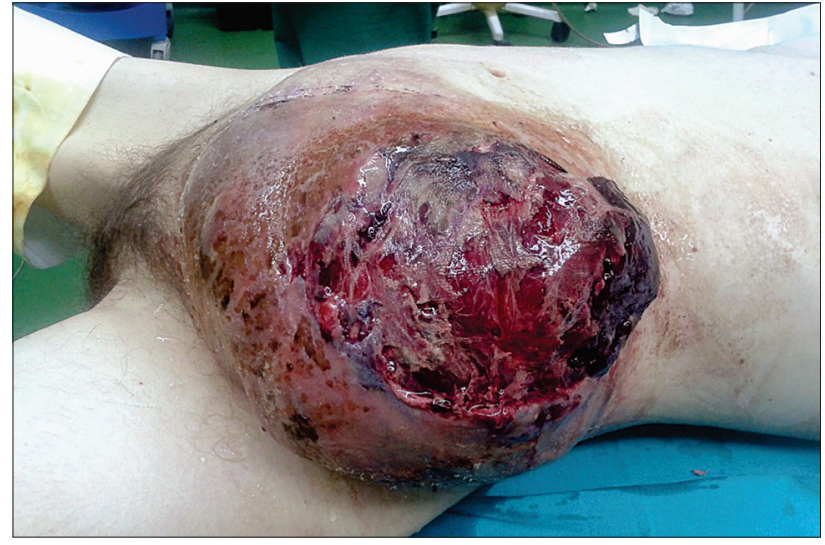

Figure 1. Large tumor, with signs of necrosis and hemorrhage, completely infiltrating the full thickness of the lower abdominal wall and necrosis of the covering skin

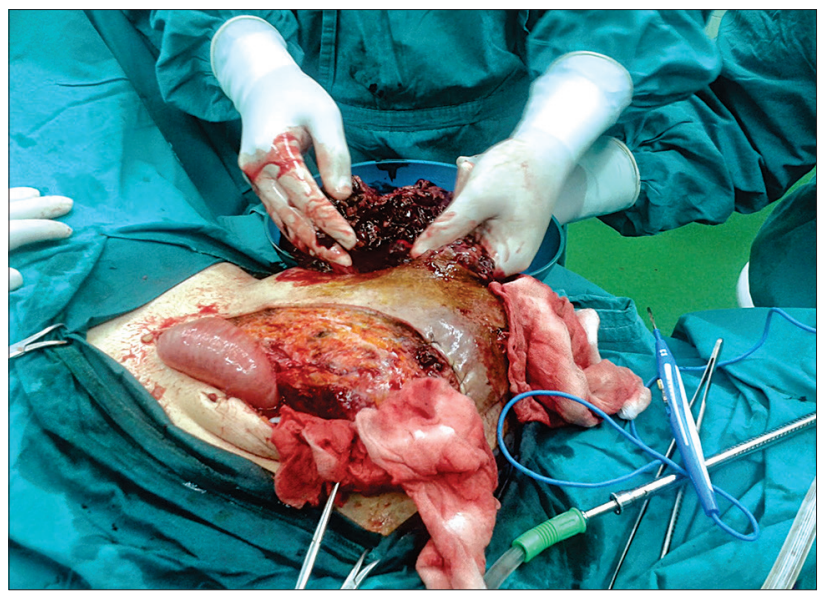

Figure 2. Tumor debulking and wide excision of the abdominal wall

Debulking of the major part of the ovarian tumor was performed, with omentectomy and wide excision of the abdominal wall. The median laparotomy was closed but the wide defect of the lower left part of the anterior abdominal wall was covered with Dexon mesh covered with Vaseline gauze dressing (Figure 2).

The size of the full thickness resected abdominal wall was about $15 \times 10 \mathrm{~cm}$. Since a prompt reconstruction was needed, it was decided to close the medial part of the defect with exposed Dexon mesh with a pedicled tensor fasciae latae fasciomyocutaneous flap, while the lateral part of the defect was covered with split thickness skin graft (Figure 3).

The patient received chemotherapy with Paclitaxel 285mg and Carboplatin $490 \mathrm{mg}$.

Results 6 months after the initial surgery are shown in Figure 4.

13 months after the initial surgery local recurrence was noted on the lateral abdominal wall and $\mathrm{CT}$ scan of the abdomen was indicated, revealing local recurrence in the lateral abdominal wall in 


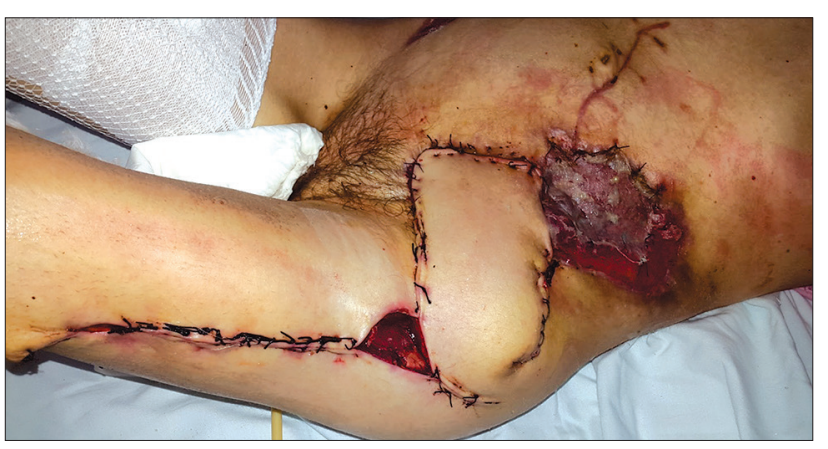

Figure 3. Reconstruction of the defect

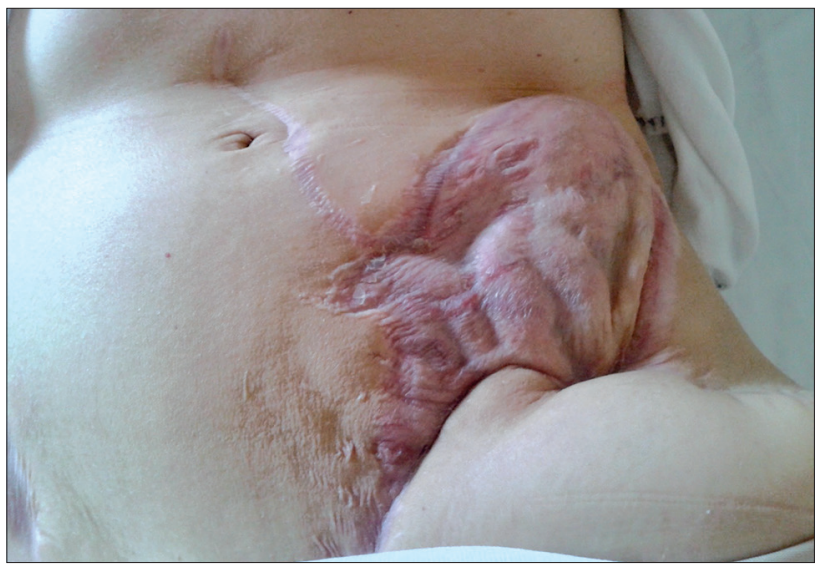

Figure 4. Antero-lateral abdominal wall 6 months after debulking and wide excision of abdominal wall

the vicinity of the previous incision, ascites and mass on the peritoneum with $3 \mathrm{~cm}$ in diameter. The lateral abdominal wall mass was excised in general anesthesia creating atypical laparotomy approach for excision of the peritoneal mass. After the operation, the patient received chemotherapy for the second time.

\section{DISCUSSION}

Basically ovarian carcinosarcoma is a mixture of two different malignancies, epithelial and sarcomatous, which behave in independent manners. This is evident in their pattern of metastasis: transperitoneal spread being almost exclusively accomplished by malignant epithelial deposits and with great difficulty by the sarcomatous component [6].

The few case series present in the literature tend to agree that maximal cytoreduction appears to correlate with better progression free survival and overall survival and the complete cytoreduction should be the goal of surgical treatment $[7,8]$.

Secondary cytoreduction in epithelial ovarian carcinoma is a standard proven to extend survival whenever R0 is achieved; on the other hand, ovarian carcinosarcoma does not seem to follow this principle [9]. On the contrary, there are reports that show statistically significant survival benefit for women who have optimum cytoreduction after surgery [1].

In case of not achieving optimal debulking of the tumor, there are also conflicting reports. The size of the residual disease after tumor debulking did not significantly impact the survival according to Barakatet al. [10], while Muntz et al. [11] state the opposite.

Research in malignant mixed mesodermal tumors of the uterus have suggested that the sarcomatous and carcinomatous components both arise from a single malignant precursor cell which has undergone metaplastic change to a sarcomatous form in some areas of the malignant tissue which contributed to the presence of both histological types [12].

Carcinosarcomas of the ovary are very aggressive tumors that are usually diagnosed at an older age compared to women with epithelial ovarian cancer. Ovarian carcinosarcomas are usually at an advanced stage at the time of the diagnosis, and survival after the diagnosis varies by stage of the disease and histological type [13]. The overall median survival period is 8 months [1].

One of the most perplexing situations ever to confront the surgeon is an open abdomen in the absence of adequate somatic substance to effect secure closure of the abdominal cavity. Major defects in abdominal wall substance pose few basic problems. First of all, there is various depth of tumor infiltration into the abdominal wall. No thought of subsequent closure should ever influence the surgeon to be less thorough or to accept less than adequate tumor resection. Closure of the abdominal wall under excessive tension regularly fails because of subsequent tissue disruption and serious wound infection. In cases where there is too great a gap between the abdominal side walls, insertion of a sheet of synthetic mesh to bridge the defect will maintain visceral position within the abdomen proper. In selection of a fascial substitute, certain fabric characteristics appear to be crucial. The substance should be pliable to preclude erosion into major structures, inert to avoid greater inflammatory response, porous to allow free drainage of the exudates and to have fiber resilience sufficient to maintain mesh integrity offering potential for permanence.

\section{CONCLUSION}

Optimal surgical cytoreduction and adjuvant chemotherapy in case of extremely locally advanced ovarian malignant Müllerian tumor provide satisfactory recurrence-free (13 months in our case) and survival period (19 months in our case). 


\section{REFERENCES}

1. Harris MA, Delap LM, Sengupta PS et al. Carcinosarcoma of the ovary. Br J Cancer 2003;88(5):654-657

2. Muller M, Dupre PF, Lucas B et al. Carcinosarcoma of the ovary. Journal de gynecologie, obstetrique et biologie de la reproduction. 2007; 36(4):399-402

3. Brown E, Stewart M, Rye T et al. Carcinosarcoma of the ovary: 19 years of prospective data from a single center. Cancer. 2004; 100:2148-53

4. Garg G, Shah JP, Kumar S et al. Ovarian and uterine carcinosarcomas: a comparative analysis of prognostic variables and survival outcomes. Int J Gynecol Cancer. 2010;20:888-894

5. Petru E, Haas J, Beganovic S et al. Carcinosarcoma (Malignant Mixed Mullerian Tumour) of the ovary- a single institution experience of 25 years. Int J Gynecol Clin Pract. 2015;2:107

6. Reed N, Millan D, Verheijen R et al. Non-epithelial ovarian cancer: ESMO clinical practice guidelines for diagnosis, treatment and follow-up. Ann Oncol. 2010; 21(suppl 5):31-36

7. Doo DW, Erickson BK, Arend RC et al. Radical surgical cytoreduction in the treatment of ovarian carcinosarcoma. J Am Coll Surgeons. 2014; 133(2):234-7

8. Sood A, Sorosky JI, Gelder MS et al. Analysis of prognostic variables and the role of surgical cytoreduction. Cancer- Am Cancer Soc. 1998; 82(9):1731-1737

9. Bacalbasa N, Balescu I, Dima S et al. Ovarian sarcoma carries a poorer prognosis than ovarian epithelial cancer throughout all FIGO stages: a single-center case-control matched study. Anticancer research. 2014; 34:7303-8

10. Barakat RR, Rubin SC, Wong G et al. Mixed mesodermal tumour of the ovary: analysis of prognostic factors in 31 cases. Obstet Gynecol. 1992;80(4):660-4

11. Muntz HG, Jones MA, Goff BA et al. malignant mixed mullerian tumours of the ovary: experiences with surgical cytoreduction and combination chemotherapy. Cancer. 1995;76(7):1209-1213

12. McCluggage WG. Malignant biphasic uterine tumours: carcinosarcomas or metaplastic carcinoma? J Clin pathol 2002; 55(5):321-325

13. Barnholtz-Sloan JS, Morris R, Malone JM et al. Survival of women diagnosed with malignant, mixed mullerian tumours of the ovary (OMMMT). Gynecol Oncol. 2004; 93(2):506-512 


\title{
Резиме
}

\section{ЕКСТРЕМНО ЛОКАЛНО НАПРЕДНАТ ОВАРИЈАЛЕН МАЛИГЕН МУЛЕРИСКИ ТУМОР КАЈ 37-ГОДИШНА ЖЕНА - ПРИКАЗ НА СЛУЧАЈ}

\author{
Ѓорѓи Јота ${ }^{1}$, Радомир Гелевски ${ }^{2}$, Зоран Караџов ${ }^{1}$, Решеп Селмани ${ }^{1}$, \\ Магдалена Генадиева-Димитрова ${ }^{3}$, Маргарита Пенева ${ }^{4}$, Весна Јовановска-Маневска $^{2}$ \\ ${ }^{1}$ Универзитетска клиника за дигестивна хирургија, Скопје \\ 2 Општа болница Куманово, Куманово \\ ${ }^{3}$ Универзитетска клиника за гастроентерохепатологија, Скопје \\ ${ }^{4}$ Универзитетската клиника за пластична и реконструктивна хирургија, Скопје
}

\section{Апстракт}

Оваријалните карциносаркоми, ретка варијанта на оваријалните карциноми, составени и од мезенхимална и карциноматозна компонента, солидни и/или цистични, месести или хеморагични, често проширени и подалеку од овариумот, се лекуваат хируршки и со адјувантна хемотерапија, според принципите за лекување на оваријалните кариноми, како резултат на малиот број на опишани случаи и недостигот на рандомизирани студии. Ова е приказ на случај на 37-годишна жена со клинички знаци на екстремно локално напреднат тумор од оваријално потекло, кој го инфилтрира долниот лев квадрант на абдоминалниот sид со некроза на препокривачката кожа. Претходната биопсија на левиот овариум и оментум покажа лошо диференциран серозен аденокарцином. Bulky-тумор со големина на детска глава, со потекло од левиот овариум и со инфилтрација во долниот лев квадрант на абдоминалниот sид, беше ослободен со широка ексцизија на абдоминалниот мид и создавање широк дефект на долниот лев дел на абдоминалниот sид, кој беше покриен со Дексонска мрежа. По заздравувањето медијалниот дел на дефектот со изложената мрежа беше затворен со фасциомиокутан флеп на петелка од тензор на широката фасција, додека латералниот дел од изложената мрежа беше покриен со кожен графт со половична дебелина. Оптималната хируршка циторедукција и адјувантна хемотерапија во случај на екстремно локално напреднат оваријален малиген мулериски тумор обезбедува задоволителен период без рецидив и преживување.

Клучни зборови: локално напреднат мешан тумор на јајниците, карциносаркома, хируршко остранување, адјувантна хемотерапија 